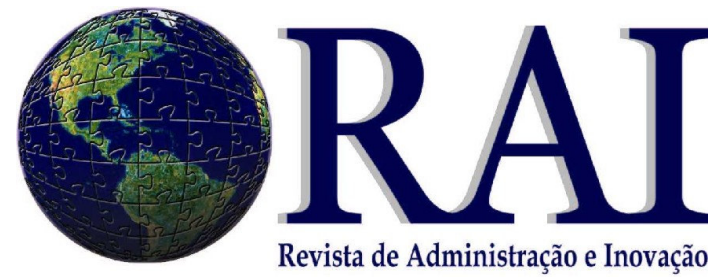

\title{
CULTURAL IDENTITY OF THE FIRST GENERATION AMERICANS: A QUALITATIVE STUDY
}

\section{Renée Gravois Lee}

Quinnipiac University, Hamden, CT 06518

E-mail: Renee.Gravois-Lee@quinnipiac.edu [USA]

\section{Mohammad Elahee}

Quinnipiac University, Hamden, CT 06518

E-mail: mohammad.Elahee@quinnipiac.edu [USA]

\section{Claudia Rosa Acevedo}

Professora do Programa de Mestrado em Administração - UNINOVE

Doutorado em Administração de Empresas, FGV-SP.

E-mail: claudiaraac@uol.com.br [Brasil]

\begin{abstract}
This research explores how meanings drawn from advertising and the mass media may contribute to the cultural identity of young adults who are first generation Americans and children of immigrants. We examine the meanings informants derive about U.S. culture and people, how they interpret the media portrayals of people of different national ancestries, and how such meaning-making affects their daily lives and cultural identity. A key finding is that informants experience a number of conflicts that stem from negotiating multiple and sometimes contradictory cultural messages received from the media, society, family, and friends. We explore the nature of these tensions and the role of the mass media in contributing to them. Moreover, we examine a variety of cultural identity management strategies employed by informants in dealing with these diverse influences. We close by discussing implications for advertising and media managers and avenues for future research.
\end{abstract}

Keywords: cultural identity; advertising; mass media; acculturation

RAI - Revista de Administração e Inovação, São Paulo, v. 1, n. 2, p. 67-83, 2004. 


\section{INTRODUCTION}

Transactions between marketers and consumers are, above all else, exchanges of meanings. -Sidney Levy, 1959

The role of advertising and the mass media in shaping our perceptions of who we are can hardly be overstated. Messages and images from all forms of media influence consumers and their frames of reference for interpreting the social world (DAVIS and GANDY, 1999; HIRSCHMAN and THOMPSON, 1997). Different media outlets ranging from advertising to plot lines to character development each play important roles in individuals' identity and ideological development (HIRSCHMAN and THOMPSON, 1997). Advertising and the mass media not only entertain us, but also serve various other functions such as informing, educating, motivating, and developing socialization skills (WRIGHT 1996).

This relationship between media messages and identity development is not merely unidirectional, however. Rather, meaning-based research has emphasized how individuals both construct and are constructed by what they learn from advertising and mass media (KATES 1999; KATES and SHAW-GARLOCK 1999; MCCRACKEN 1986; MICK and BUHL 1992; PARKER 1998; RITSON and ELLIOT 1999; THOMPSON and HAYTKO 1997; THOMPSON and HIRSCHMAN, 1995; THOMPSON and TAMBYAH 1999). Moreover, individuals bring wide-ranging and diverse personal frames of reference to their interpretations. In particular, individuals of different national ancestries bring an array of cultural expectations, life experiences, and interpretive strategies to their media encounters.

In this study, using in-depth interviews with young adults who are children of immigrants, all being first generation Americans, we explore cultural meanings drawn from the mass media and the role that media messages may play in the formation and expression of their cultural as well as individual identity. Identity development is influenced by perceptions of self and the environment (BENSON et al. 1992), both of which individuals learn, to a large degree, from the mass media (FABER, O'GUINN, and MCCARTY, 1987). Since cultural identification may influence the way one develops meaning from mass media, while at the same time media meanings play an important role in the development of cultural identity (APPIAH 2001; GIBSON, 2001), we wish to explore this dynamic process. Our informants collectively represent eight different countries of ancestry from three continents

First generation Americans present an interesting case study for examining such meaning-making and how it may influence their individual identity which is often torn between the their ancestral cultures and the culture of their adopted home. First, individuals of different national ancestries bring diverse cultural frameworks to the interpretive process. That is, individuals perceive (filter) advertising and mass media messages through a framework that is also "contaminated" by the culture of the dominant society as well their own personal history. They construct a "pastiche" of images gathered from diverse societal influences (e.g., advertising, media, family, friends, schools) and tie them to images of the dominant culture that surround them in their everyday lives (HIRSCHMAN and THOMPSON, 1997). Thus their interpretive lenses draw on elements of both the host culture and their country of ancestry. Stated differently, they simultaneously bring both the perspective of an American native or "insider," as well as the viewpoint of a visitor or "outsider."

Second, for children of immigrants, development of cultural identity may be complicated by intergenerational conflict. They are faced with the challenge of navigating

RAI - Revista de Administração e Inovação, São Paulo, v. 1, n. 2, p. 67-83, 2004. 
both the dominant US culture in which they were raised, as well as the ancestral cultural values instilled in them by their parents. Such dual navigation, especially when these young adults and their parents may still be in the process of learning to decode the symbols, norms, mores, sanctions, beliefs, morals, and customs of the United States (US). culture, may accentuate the problem of value conflicts (GHASARIAN, 1995). Third, since first generation Americans frequently aspire to identify with the U.S. dominant culture (GIBSON, 2001), mass media messages as well as the pastiche they construct are important influences they may draw upon as guidelines for how to build their images to others and behave socially.

\subsection{RESEARCH QUESTIONS AND IMPORTANCE OF THE STUDY}

Identity development is a never-ending, life-long process (ERICKSON, 1968). This study explores how meanings drawn from the mass media may contribute to the cultural identity of young adults who are first generation Americans. The paper specifically addresses two questions:

1) What meanings do first generation Americans derive from the mass media? About U.S. culture and people? About people of different national ancestries?

2) How do meanings drawn from the mass media contribute to informants' cultural identity development? For instance:

- How do informants' background, life experiences, and cultural context relate to their meaning-making?

- What strategies do informants follow in connecting media influences to their cultural identity?

This research is important because by examining mass media interpretations within the broader social context of individuals' life experiences, we can better understand some of the connections between advertising, mass media, and consumers' use of media messages in their personal lives. As such, we build on recent research that has examined what consumers $\underline{d o}$ with media messages, rather than focusing only on what messages may do to consumers (HIRSCHMAN and THOMPSON 1997; PARKER, 1998). Examining consumers' interpreted or perceived meanings are important for the core interests of marketing (THOMPSON, 1997) as well as for the management of customer relationships (WEBSTER, 1992). Further, in spite of increasing interest in better understanding and targeting immigrant markets in the US, little academic research has focused on how immigrants or their children interpret messages from the mass media or how these influences may impact their acculturation to the US.

This paper is organized as follows. First, in the background section, we highlight a number of related literatures that cast light on changing societal influences on immigrants and their children, the challenges of navigating two cultures, consumer/mass media relationships, and the role of the media in cultural identity development. Second, we provide an overview of our methodology. Third, we provide an in-depth analysis of the data collected from 13 participants, whom we refer to as "informants." We posit that informants experience a number of conflicts that stem from negotiating multiple and sometimes contradictory cultural messages received from the media, society, family, and friends. We explore the nature of these conflicts and how the mass media plays a role, the strategies informants employ in

RAI - Revista de Administração e Inovação, São Paulo, v. 1, n. 2, p. 67-83, 2004. 
dealing with these diverse influences and tensions, and how this complex meaning-making process impacts their cultural identity. Fourth, we close with a discussion of implications for both advertising and media theory and practice, as well as ideas for future research.

\section{BACKGROUND}

\subsection{CHANGING INFLUENCES ON IMMIGRANTS AND THEIR CHILDREN}

From its beginning, the US has been a land of immigrants, attracting people from all over the world. The influx of immigrants into the U.S. has steadily increased over the years and the "future character of the American society and economy will be intimately related to the adaptation of the children of today's immigrants," who now constitute one out of every five children in the U.S. (SUAREZ-OROZCOS and SUAREZ-OROZCOS, 2001, p. 3). Concurrent with the growth of immigration, social scientists have studied the process of acculturation and assimilation from various perspectives. For instance, marketers have studied immigrants with respect to their shopping behavior, purchase decisions, and media use, to name a few see, e.g., (WEBSTER, 1997; NICHOLLS, 1997; CHAFFEE, 1990).

The US has demonstrated a unique ability to assimilate its immigrants and turn "foreigners" into "locals." In fact, after the October 2005 riot in France perpetrated by descendants of immigrants from North Africa, most major newspapers in the US and Europe opined that the US has been much more successful than European countries in assimilating its immigrants to the mainstream population. Despite the relative success of the US in assimilating its immigrants, it is worth noting that the US too faces new set of challenges due to some new developments. Unlike in the past when the US was considered a "melting pot" and emphasis was placed on becoming assimilated to the US society, the recent trend in the US is maintaining and promoting diversity, as can be evidenced by the proliferation of ethnic restaurants, publication of newspapers in different languages, requiring high school students to learn a second language, White House dinners and receptions to for different religious groups (e.g., Iftar Party for Muslims and Diwali for Hindu people), celebrating the national days of different countries by holding parades in New York and other big cities, etc. Further evidence about this rowing emphasis on diversity can be found in a number of practices such as the US government issuing a special category of immigrant visa called Diversity Visa through lottery to people from countries that are underrepresented in the US (www.usais.org), educational institutions and government agencies more aggressively recruiting people from diverse backgrounds, and the establishment of bilingual schools in various parts of the country (Rothstein 1998). Such a paradigm shift may have a profound impact on the pace, extent, and nature of acculturation and assimilation of immigrants and their children.

New challenges have also emerged for immigrants and their children to assimilate with their host culture. In the past, immigrants had limited contact with their ancestral cultures, from which they were separated by oceans. But now, thanks to major technological breakthroughs, immigrants can make frequent phone calls to their home country at a low cost, watch their home country's television programs through satellite or dish antennae, and use the Internet to keep in touch with their home country and culture. The proliferation of ethnic restaurants, groceries, and clubs and organizations based on national ancestry also allows immigrants and their children to remain exposed to their ancestral culture.

RAI - Revista de Administração e Inovação, São Paulo, v. 1, n. 2, p. 67-83, 2004. 


\subsection{NAVIGATING TWO CULTURES}

First generation Americans often find themselves in a precarious situation of navigating two cultures- the US and their ancestral culture. Navigating in the US culture requires the slow and often painful process that anthropologists call "acculturation." Acculturation can be defined as the changes that take place among immigrants who enter into contact with a new society (BERRY \& SAM, 1997). The acculturation process and the various strategies that immigrants follow in becoming "American" is important to know since the process has a far reaching consequence on how immigrants and their children draw meanings from the media.

\subsubsection{Cultural Identity and the Mass Media}

Identity is typically defined as a goal to be achieved and is generally associated with positive self-concepts and high levels of self-esteem (ALLEN, HOWARD, and GRIMES 1997). A review of relevant literature suggests that identity is a multi-dimensional construct (GARZA and HERRINGER, 1986) that may be influenced by a number of "distinct vectors of influence" such as gender, social class, employment status, lifestyle choice, religion etc. (DAVIS and GANDY, 1999, p. 30). As pointed out earlier, Identity development is influenced by perceptions of self and the environment (BENSON et al. 1992), both of which individuals learn, to a large degree, from the mass media (FABER, O'GUINN, and MCCARTY, 1987).

The identity development of first generation Americans may take place in different ways than that of second and subsequent generations. Their parents may, consciously or unconsciously, instill in them values of their home country. And compared to children of US citizens, they are likely to have different experiences in their social encounters. As such, first generation Americans may bring different interpretive styles to the media and draw meanings from advertising and the mass media in a different way than those whose parents are not immigrants.

Much of the published research on identity has concentrated on race, gender, economic status, and ethnicity, and has examined identity development from the points of view of social cognition (DERVIN, 1996), public policy and political choice (DAWSON, 1994), and sequential developmental process (ALLEN, HOWARD, and GRIMES, 1997; CROSS, 1971; PARHAM and WILLIAMS, 1993). The few studies that have investigated the relationship between media and identity e.g., (DAVIS and GANDY, 1999; JONES, 1990; ALLEN and BIELBY, 1979) focused primarily on media content, media orientation, and evaluation of media programs. None of these studies explored media meanings specifically from the viewpoint of informants, nor did any of the studies examine the interrelationship, if any, between meaning-making from the media and identity development. In an effort to fill this gap, our study provides an in-depth examination of how informants draw meaning from the media, connect those meanings to their evolving identities, and use those derived meanings in their daily lives.

\section{METHODOLOGY}

We conducted 13 in-depth interviews with young adults who are first generation Americans. Collectively, they represent eight different countries of ancestry: China, Korea,

RAI - Revista de Administração e Inovação, São Paulo, v. 1, n. 2, p. 67-83, 2004. 
Portugal, Brazil, India, Pakistan, Italy, and the Dominican Republic. Ten of the informants are first generation immigrants. Participants ranged in age from 19-24, ten were female, and three were male. All informants have various degrees of contact with their country of ancestry and many of them are bilingual.

We employed a purposive and convenience sampling strategy, drawing from students enrolled in a New England university. College students were purposely selected because this population group is a fruitful segment for exploring issues of identity management, is believed to be active in the social use of mass media (RITSON and ELLIOT, 1999), and compared to young children, is less likely to face media mediation by their parents Through purposive sampling, we sought variability in both country of ancestry and college major, since we wanted our sample to represent a range of backgrounds and interests.

We conducted individual tape-recorded interviews, which were later transcribed. During the interviews, we broadly explored the meanings informants derive from the mass media about American people and culture, with a particular focus on the use of such meanings in their everyday lives. Each author first analyzed the data independently, and then compared and discussed the analysis and emerging themes, which led to development of the final coding scheme and interpretation. We used an iterative, data-driven approach to the analysis, analyzing the data both within and across informants, and tacking back and forth multiple times between the literature and the data (MCCRACKEN, 1988; SPRADLEY, 1979). We went through several iterations of the analysis as we identified, challenged, expanded, and refined the emerging themes. Throughout the paper, the meanings that informants ascribe to mass media messages are discussed as texts and narratives, and the paper analyzes this textual data.

\subsection{ANALYSIS AND FINDINGS}

Advertising and the mass media had a considerable impact in informants' daily lives and struggles over identity. This influence was not merely a one-way transfer of meaning from media to receiver, however. Rather, the consumer/media relationship was complex, multidimensional, and conflict-ridden. An overarching finding in our research was how the mass media played a role in informants' navigation of the challenges of integrating American culture with their culture of ancestry. They shared story after story of conflicts that stemmed from negotiating diverse and sometimes contradictory cultural messages received from the media, family, friends, and schools. Our analysis explores such tensions.

First, we highlight how informants actively looked to the media for education about what it means to be an American and how to be an American. Second, we identify a number of conflicts informants encountered in negotiating two cultures and attempting to come to grips with their own identity amid competing and contradictory messages from the media and other societal influences. Many of these conflicts stem from feeling varying degrees of distance from their perceptions of how they should be/act as Americans, as well as conflicts experienced from negative and stereotypical media portrayals of people of different ancestries. Third, our analysis highlights some of the complex strategies informants employed to deal with these diverse influences, and how this complex meaning-making process impacted their cultural identity.

RAI - Revista de Administração e Inovação, São Paulo, v. 1, n. 2, p. 67-83, 2004. 


\subsection{MASS MEDIA AS A TEACHER, TRANSLATOR, AND TRANSMITTER OF VALUES}

Study participants emphasized what a critical role the media plays in teaching them about American culture and people. Their narratives revealed that the media has taught them how as Americans they should think, behave, and act - generally how they should carry themselves in life. For example, our informants commented:

"[...] I learned how to dress, how to take taste as an American, how to behave, how to dress, how to act, how to judge, how to react certain things, how to laugh."

"A lot of times, because my parents were not able to teach me different things about American culture, it took an outside facilitator to help me you know adapt. It was like the TV was a babysitter."

Thus informants relied on the media as a translator or facilitator to teach them about being an American. When asked by the researchers about the common images portrayed in the media, the common answers from all informants was "material wealth" and "achievements." In large part, the informants described the typical American as a white male with a professional office job, a nuclear family, and a drive for material wealth and success as his primary life goal. An important finding was that the informants had internalized these values as their ideal American way of life and aspired to achieve this ideal media image of what life as an American should be-a life full of educational and career accomplishments, family, a nice house, material goods, high quality of life, and success. As one informant put it:

"[...] a lot of money. And that is how I am similar [...] I want to have a lot of money so I can help out my family, too. And I want to be happy in life so I am not struggling with money or stress or problems."

This relationship to the mass media - striving to emulate a media ideal - is similar to the inspiring and aspiring strategy described in Hirschman \& Thompson (1997).

While informants actively looked to the media as a teacher and cultural transmitter about American culture, people, and values, they did not unilaterally accept everything the media propagates. Rather, the process of drawing meaning, determining what to filter in and out, and relating media messages to their everyday lives and cultural identity was diverse and complex. Next we turn to some of the conflicts they experienced trying to make sense of the various and competing messages they encountered.

\subsection{CULTURAL IDENTITY CONFLICTS}

A key finding in our study is that making sense of mass media messages in concert with other societal influences introduced a number of conflicts for informants. A major challenge they faced was coming to grips with their own identity and social place when the influences of their two cultures frequently pull them in opposite directions. For instance,

RAI - Revista de Administração e Inovação, São Paulo, v. 1, n. 2, p. 67-83, 2004. 
while informants in some ways seem to identify predominantly with the American culture they were raised in, they do not feel $100 \%$ American, but rather feel various degrees of connection to each country. Some informants spoke of the harsh clash between the U.S. culture and their ancestral culture, and how they felt split between two cultures.

"It (my home) was kind of war zones...It is very difficult when two cultures have very different values that are very unique to each. And it's very hard to incorporate such differences into your lifestyle."

mixed."

"It's hard to tell (whether I feel American or Portuguese) [...] just culturally I am

"I still don't feel completely American [...] I feel a good part of me is still living (in my parents culture). And my parents, they consider me American and they say that the way that I live is completely American, but I don't feel that way. I feel that I am influenced by both cultures and that I am not $100 \%$ any one culture."

Informants explained how the quest to find some degree of balance between two cultures required consistent effort and struggle. Many of these tensions were manifest in informants' grappling with issues of identity, particular questions about "Who Am I?" Informants' narratives revealed that coming to grips with their cultural identity is not only complex but also rife with conflict. They detailed the challenges of trying to simultaneously manage their own goals of who they want to be, and integrating those aspirations with what their parents/family/friends expect, as well as what the media and society tell them Americans should be like. These conflicts between informants' and others' expectations of them created a great deal of internal tension for them. Moreover, media images of what it means to be an American in many cases exacerbated such conflicts. Our informant with Chinese background described constant pressure she felt from the media to be fashionable and wear classier clothing created worry and confusion for her about who she should be and what she should look like and wear.

"[...] So the images that I saw at TV was actually what I thought I was supposed to act. Yeah. It was weird. And what I saw on TV, what people wore, fashion was such a big thing... Like classier clothing-I thought that was what I needed, to actually fit in. And I would never ever like worry about that until when I saw on TV. And it was media it was the major thing for me [...] So it's definitely a big conflict in how to be an American when my image was how to become an American, I mean I didn't know exactly how to be an American with how to act [...] I tried to look like an American [...] They're mostly blonde hair, blue eyes, skinny, looks like a Barbie doll, pretty much, Barbie doll. And that's how I tried to change myself. I tried to dye my hair blonde; I still have colored blue contacts. I dress differently. I dress like an American. I tried to be an American. I tried to change my own background and it was weird, it was something weird."

One informant, whose family emigrated from Brazil, too expressed concerns about many internal tensions she faced in desiring to achieve the ideal beautiful appearance that is widely promoted for American women.

"Magazines are not good for girls like me because when you pick up those fashion magazines and you see how thin and beautiful they are, you're like "great" (said in sarcastic tone). And I know my grandmother is like, "eat, you're too thin girl, eat." On these magazines, even TV, all you see is bones. I think Americans are obsessed with beauty and being thin and being

RAI - Revista de Administração e Inovação, São Paulo, v. 1, n. 2, p. 67-83, 2004. 
perfect and it makes me feel fat, it doesn't make me feel so good. In TV and even pregnant actresses looks better than I do in real life on the show "Friends." [...] I have brown hair, brown eyes. So there we go-strike number two [...] Sometimes yeah, you flip through the magazine and you want to be blond hair blue eyes, how many times to I say I wish I had blue eyes [...] But who doesn't wish they could look like Heather Locklear or Cindy Crawford? We all wish to be that perfect person that the TV shows."

Our informants painted a vivid picture of how the media paints a fairly unidimensional picture of how individuals should look and dress, and how straying from this norm can open up an individual to ridicule. Attempting to emulate the media ideals, but at the same time being different from these images, created conflict for them. The participant with Korean ancestry felt the ridicule that resulted from his attempts to be more American. His friends back at home in Korea call him a derogatory name because while he looks Asian, his actions are American.

"A lot of my friends [...] they kind of call me term, a slang term like a banana kind of thing. Like, I look different, but I act Caucasian."

This was a common conflict experienced by informants - that they were "too American" for the liking of parents and some of their family and friends. Parents seemed to express the most disapproval, conveying to informants that they did not want them to be like Americans as portrayed in the media, but rather wanted them to be more like people from the ancestral culture. Comments from a few other informants in this express similar disapproval from parents:

"My mother starts crying (when she learns) that I feel American. My allegiance would be to the US [...] This is my home, this is where I have grown up. This is all of the memories that I have. Why would I leave? [...] I would fight for this country, for its beliefs, for what it stands. And I definitely feel American. I see my parents' country as a vacation, as a nice place to retreat and have family to be with. But here this is my home. My heart belongs to it. My first language now has become English. I think in English, I dream in English. Everything is American. My parents on the other hand, don't want to hear that."

"As an Americanized woman, me, I definite have many fights with my parents with what I wanted to do. I wanted them to desire or to draw half of me. But I want to draw my own path. But that [drawing my own path] wasn't allowed either [...] My parents actually wanted me to become friends with the more on my own culture; they want me down with more Chinese friends, more stick with your own kind typical thinks like. I always did in some ways, but I was more drawn to American people."

Another informant summed up this conflict by expressing how she so often feels "tested" about her allegiance and about how to behave in a given situation. Should she act Indian? Should she act American?

"You're always tested whether to be more American. Whether when you go home you want to be more Indian because your parents are pushing you towards that, and then you have friends that are your Indian friends, and then your American friends, and it's really hard to have that balance. I would have to say it's very difficult every single day you are faced with it in some way or another."

As this part of our analysis demonstrates, while informants expressed great desire to be true to both the US where they were raised and their country of ancestry, they sometimes felt that they were walking a thin line trying to balance the multiple competing influences of

RAI - Revista de Administração e Inovação, São Paulo, v. 1, n. 2, p. 67-83, 2004. 
self, family, friends, and the media. This constellation of influences created a number of conflicts and had a significant impact on questions of cultural identity, particularly the "Who am I" question. These conflicts included internal tensions resulting from the quest to achieve an American "ideal" for beauty or fitness, derogatory reactions or even ridicule from others about informants' differences in appearance or actions, and disapproval from parents, family, and friends about informants' being "too" American.

\section{STRATEGIES FOR NAVIGATING MULTIPLE CULTURAL INFLUENCES}

Informants employed a number of strategies to cope with these diverse influences and conflicts, including alternating between the two cultures, adapting their behavior to integrate elements of both cultures, and deconstructing and/or distancing themselves from societal messages with which they disagreed.

\subsection{ALTERNATING AND ADAPTING}

Existing literature suggests that children of immigrants often develop a dual system of values and contextually shifting behavior to deal with the contradictions between their ancestral and US cultures (GHASARIAN, 1995). Informants explained how it is very challenging to have to consistently alter their behavior based on the cultural circumstances. Since behavioral expectations are different in different cultures, they always have to be alert to how to act in a particular situation. In this regard, one informant said:

"If I' $m$ in the United Sates I need to act like this, but if I'm in Brazil I need to act this way. And sometimes when people look at me they might not understand the fact that I have two cultures in me."

This strategy resembles what LaFramboise et al. (1993) labeled as the alternation strategy of second culture acquisition. However, in contrast to this strategy of alternating between the cultures, we also found that other informants employed a strategy that blended elements of the American culture with their ancestral culture, and they adapted their behaviors in an attempt to integrate both cultures. Our informants often drew upon elements of both cultures - by either alternating between two cultures or finding ways to fuse the two. Such strategies represented attempts to adapt to and accommodate the many conflicting messages they faced in their daily lives by changing their behavior.

In contrast, a second key set of strategies informants employed was to question some of those messages - to deconstruct and distance themselves from media and societal messages with which they disagreed. Perhaps the most prominent example of this strategy was informants' deconstruction of what they perceived as frequent and sometimes downright blatant media stereotypes of ethnic and minority subcultures. They expressed a great deal of dismay and disdain for negative and stereotypical media portrayals of people of different ancestries.

"The subcultures that we see on TV like the Hispanic and African American are kind of shown on TV shows and movies, are shown living in the inner cities and parts of gangs, so that in certain respects are not shown in a positive light. ... Basically, American media caters to the white audience and don't portray [other cultures] fairly.

RAI - Revista de Administração e Inovação, São Paulo, v. 1, n. 2, p. 67-83, 2004. 
Informants were quick to distance themselves from such inaccurate and derogatory portrayals - using their explanation of and anger about media stereotypes to explain who they are not, what their ancestral cultural is not, and what others of similar ancestry are not.

Another way informants actively distanced themselves from demeaning portrayals was to emphasize the negative outcomes of such portrayals. These outcomes included ignoring positive characteristics of minority groups, creating stigma, and reinforcing inaccurate and negative assumptions about people of different nationalities.

"There are a lot of stereotypes [in the media]...certain stereotypes are really wrong as they create a kind of stigma - where they are stuck with that person, you know. Or a stigma where you'll go and people will assume something before they get to know you. So I think it can be negative."

"These images can cause negative feelings from the public because there is a group of people who cannot separate what's television from what's real. So I think a lot of times people are prejudiced against people because of what they see on TV."

The data revealed an interesting contrast between informants' interpretations of the portrayals of Americans versus people of other nationalities. While they were quick to criticize and distance themselves from minority portrayals, they did NOT engage in a similar level of deconstruction or critical evaluation of how the mass media portrays the typical American person or American values. Rather, informants expressed great desires to emulate American portrayals (e.g., work, family, success), and the conceptions informants held of the typical American way of life seemed to be in harmony with images that the mass media portrays.

\subsection{PARTIAL ASSOCIATION STRATEGY}

Some of our informants identified in part with the media images. They reported that they shared some of the same values of the American society, but in the same time part of their values were different. One informant explained how he "picks and chooses" those cultural values that are most important to him, and that his unique way of blending American and his ancestral values yields a better way of living than that of most Americans. Similar views were expressed by a number of other informants. One informant explained:

"I am similar to the typical American person portrayed by the mass media in that I find myself very materialistic towards things. A lot of my life is based on material things. My main goal in life is more towards having a house and being set with money not having problems. That is more my goal than happiness and just living a good life without material things. This is similar. Cause a lot of Americans' main goal in life is to have a big house, a nice car, two kids and a lot of money. And that is how I am similar [...] But I try to do things differently in a way that improves the way that Americans live their lives. I try to just do things my way but make them work in society that's doing things a certain way. So I am trying to be similar, but also different and try to make my difference and use my difference to gain acceptance."

\section{DISCUSSION}

Our investigation shows that mass media played a significant role in teaching first generation Americans about American culture and its people. We found that informants tend

RAI - Revista de Administração e Inovação, São Paulo, v. 1, n. 2, p. 67-83, 2004. 
to perceive American culture and values embedded in their parents reasons to come to U. S. Their interpretations of the typical American values seem to be similar to the reasons that brought their parents to US, that is better opportunities in life (work, education, wealth, career, freedom).

Our findings showed that the meanings drawn from the mass media contribute not only to develop cultural identity conflict in the young adult but also to help them to apply the Fusion strategy to cope with two cultures. Those results extend previous research furthering the literature of mass media meanings and cultural identity development.

We found that informants were experiencing strong identity conflict with many aspects. The first aspect of this conflict is the feeling of being part of the two cultures or to belong to none. A second dimension of this conflict relies on the effort to look and behave as an American. A third aspect of this conflict appears to be how to incorporate the American culture without losing their parents' culture. Another dimension of this conflict stems from the perception of living in cultures that present different norms and obligations and as a consequence demand from them opposite behaviors. In this manner, informants feel obliged to adapt their behavior depending on the cultural context.

The study intended to shed light on the strategies informants follow in connecting media influence to their cultural identity. Our results showed that our informants employed two interpretive strategies: 1) partial association and 2) deconstructing and rejecting. While the first strategy was applied to images of American people, values and way of life, the deconstructing strategy was employed mostly to images of non-American, but also to the idealistic approach of the media.

The "partial association" strategy was employed because they seem to incorporate part of the American values but not one hundred per cent of it. In fact, the way of life, that is, freedom, wealth, material concerns, education, career and family were accepted as things they want to acquire to their life. On the other hand, according to the informants' perceptions, they don't assimilate an important aspect of the American values and behave, that is, "to work too much and not to enjoy life" or "to accumulate more and more material things and not be happy."

Those findings provide empirical support for the results of previous "desconstructing" strategy research (HIRSCHMAN and THOMPSON, 1997) and also extend the mass media relationship research suggesting a new strategy, that is, the "partial association" strategy. In this manner, our study provides another theoretical contribution to the literature because it suggests a fourth strategy of how consumers bring mass media meanings to their lives.

Our study indicates that first generation Americans look upon the media as a guide and teacher as well as cultural transmitter about American culture and people-its values, mores, norms, and behavior. Yet, while in some instances the media had a profound influence on informants' attitudes, behavior, and sense of self, in some other instances, they actively rejected and/or modified media messages to suit their own beliefs. They shared many stories of struggles to reconcile their aspirations of what they want to be and achieve in life, with that of what their parents/family and peers expect. Moreover, their narratives revealed how both these conflicts and the strategies to face and overcome such conflicts are influenced by what they learn from the mass media.

Finally, our analysis demonstrated a variety of identity management strategies informants used to make sense of and respond to the multiple and often competing influences impinging on their sense of self and place. Some of these key strategies identified here

RAI - Revista de Administração e Inovação, São Paulo, v. 1, n. 2, p. 67-83, 2004. 
included active attempts to look/act/be more like the ideal American images informants perceive from the media; selective adoption of certain U.S. cultural traits; and in some cases, deliberate attempts to distance themselves from U.S. culture by rejecting some US cultural norms and criticizing stereotypes of people of different ancestries. Moreover, the study illustrated how informants' struggles related to cultural identity shape which media messages they attune to and how they draw meaning from and relate to the mass media. The study shoes a variety of ways that informants accept, reject, combine, and adapt the diverse media and other influences to arrive at their own interpretations, and how this complex meaningmaking process impacts them personally.

\section{LIMITATIONS AND FUTURE RESEARCH DIRECTIONS}

While this study deepens our understanding of how children of immigrants assign meanings to what they see in the mass media and what strategies they follow to cope with their identity and cultural conflicts, it also suffers from a number of limitations that provide opportunities for future research.

This study used college students from a variety of ethnic backgrounds as subjects. Since consumers vary in their responses to targeted advertisements according to their social category (AAKER, BRUMBAUGH, and GRIER 1997), it is possible that the ethnic background of the informants play a role in how they draw meanings from the mass media and apply those meanings in their lives. Therefore, future research should examine different ethnic and cultural groups and investigate the role of culture, in any, in mediating or moderating the role of media in the lives of immigrants and their offspring. This study focused only on college students. As people join the workforce and encounter new experiences in life, their beliefs, values, and outlook often change as a result of their life experiences. Future research should therefore use a broader sample that represents not just different cultural groups, but also different age groups representing different age groups and social, political and economic positions.

The participants in our study strongly complained against the negative stereotyping of foreigners in the mass media. Future researchers should investigate how negative stereotyping and stigmatizing affects foreigners' assigning meanings to advertisements.

Because of the newness of the topic and our limited knowledge of the subject matter, the focus in this paper was very general and broad - we focused on the entire mass media. Since we now have a general understanding of the subject matter, future researchers may focus on different types of mass media (e.g., newspapers vs. radio vs. TV vs. the Internet etc.) as well as different types of outlets (e.g., commercials, news, programs, etc.).

\section{CONCLUSIONS AND IMPLICATIONS}

The findings of the study enhance of our understanding of how children of immigrants and first generation Americans draw meanings from mass media and what strategies they follow in handling the conflict between their parents' ethnic culture and U.S. culture.

The findings underscore the importance of culturally sensitive messages, i.e., messages should convey the cultural values of a given group in such a way so that the audience finds similarities between their cultural norms and values and what is portrayed in

RAI - Revista de Administração e Inovação, São Paulo, v. 1, n. 2, p. 67-83, 2004. 
the media. Previous research shows that advertisements that used African-American models but lacked African-American cultural sensitivity failed to convince African-American youths to identify themselves with those advertisements (BRISTOR, LEE, and HUNT 1995). As a number of our informants described how they rely on certain aspects/programs of mass media to make various commitments and decisions in their personal lives, it is imperative that marketers make an effort to make the messages that they convey through mass media to be embedded with cultural cues that the target audience can identify with. As the diversity in U.S. population is likely to grow in the coming years, marketers need to pay special attention to make their messages purposefully polysemic (i.e., meaningful to the target audience).

Second, most of our informants complained against negative stereotypical presentation of foreigners and their ethnic cultures in the media. Previous research shows that the negative portrayal of African-Americans led to low self-esteem among African Americans (DAVIS and GANDY, 1999; STROMAN, 1984; GRACES, 1980). Because of the reported negative portrayal of foreigners as well as the ethnic cultures of the informants in the mass media, it is possible that a high level of exposure to mass media, and especially to TV commercials and programs, may lead to low self-esteem among the immigrants. The third implication, which is related to the second one, is that because of perceived negative stereotypical portrayals of their ethnic cultures in mass media and especially in the TV, children of immigrants and first generation Americans may resort to a strategy of selective or purposive use of media. In other words, they may prefer one particular media to another (e.g., the Internet over TV; newspaper over radio etc.). Similar selective use of media was found in African-American people who, compared to other ethnic groups in the U.S., rely more on radio than TV to fulfill functions that TV is unable to fulfill (LAGETTE, 1994; STARK 1993).

With the changing demographic composition of the US society, target marketing is becoming more complex and marketers are faced with the challenge of reaching the consumers in new but more effective ways. It is therefore not surprising that researchers have called for "a meaning-based approach to understanding advertisements and consumer behavior" (GRIER and BRUMBAUGH, 1999, p. 79). While there is much work to be done, this study is offered as a first step toward understanding the immensely important aspect of assigning meanings by the children of immigrants and first generation Americans to what they see in mass media and the strategies they employ to manage their cultural identity conflicts. An understanding of such cultural identity management strategies would not only be beneficial for marketers, but also for educators and social formulators who will have to deal with more and more people of different ethnic backgrounds.

Our findings have important implications for advertisers. Because first generation people tend to be more critical with mass media images, advertisers should be more accurate to the real life when addressing this group of people. Moreover, when trying to target this group, practitioners should include in the add elements of the national group that the specific segment who is been targeted comes from. In addition, our findings suggest that mass media images contribute to produce conflict in first generation people. So practitioners should avoid elements in the adds that contribute to generate these conflicts (as for example showing typical American as white people only).

RAI - Revista de Administração e Inovação, São Paulo, v. 1, n. 2, p. 67-83, 2004. 


\section{REFERENCES}

AAKER, J. L. A. BRUMBAUGH, M. and GRIER, S. L.. "Non-target Market effects and Viewer Distinctiveness: The Impact of Target Marketing on Attitudes, Working Paper, Stanford University, 1997.

ALLEN, M., L. H. and GRIMES, D. Racial Group Orientation and Self-Concept: Examining the Relationship Using Meta-analysis. Howard Journal of Communications, v. 8, n. 4, 1997, p. 371-386.

ALLEN, R. L. and Bielby, W.T. Blacks' Attitude and Behavior Toward Television. Communication Research, v. 6, n. 4, 1979, p. 437-462.

APPIAH, O. Ethnic Identification on Adolescents' Evaluation of Advertisements. Journal of Advertising Research, v. 41 n .5, 2001, p. 7-22.

Benson, M.J., P.B. HARRIS and Rogers, C.S. Identity Consequences of Attachment to Mothers and Fathers Among Late Adolescents. Journal of Resident Adolescent. v. 2, 1992, p. 187-204.

BRISTOR, J. M., LEE, R. G. and HUNT, M. R.. Race and Ideology: African-American Images in Television Advertising. Journal of Public Policy and Marketing, v. 14, n. 1, 1995, p. $48-59$.

CROSS, W.E. The Negro-to-Black Conversion Experience: Toward a Psychology of Black Liberation. Black World., v. 20, 1971, p. 13-27.

DAVIS, J. L. and GANDY, O. H. Racial identity and media orientation: Exploring the nature of constraint. Journal of Black Studies, v. 29, n. 3, 1999, p. 367-397.

DAWSON, M.C. Behind the Mule: Race and Class in African-American Politics. Princeton, N.J.: Princeton University Press, 1994.

DERVIN, B. Sense-making Packet: As of October 1996. Columbus, OH: Authors, 1996.

ERICKSON, E. Identity: Youth and Crisis. New York, NY- Internation Publishing, 1968.

FABER, R.J., T.C. O'GUINN and MCCARTY, J.A. Ethnicity, Acculturation, and the Importance of Product Attributes. Psychology and Marketing, v. 4, n. 2, 1987, p. 121-134.

GARZA, R.T. and HERRINGER, L.G. Social Identity: A Multi-dimensional Approach. Journal of Social Psychology, v. 237, n. 3, 1986, p. 299-308.

GHASARIAN, Christian. Education and Its Consequences: Value Conflicts in an Immigrant Community. Social Education, v. 59, 1995, p. 78-81.

GRIER, S. A. and BRUMBAUGH, A. M. Noticing Cultural Differences: Ad Meanings Created by Target and Non-target Markets. Journal of Advertising, v. 28, n. 1, 1999, p. 79-93.

RAI - Revista de Administração e Inovação, São Paulo, v. 1, n. 2, p. 67-83, 2004. 
HIRSCHMAN, E. C. and THOMPSON, C. J. Why Media Matter: Toward a Richer Understanding of Consumers' Relationships with Advertising and Mass Media. Journal of Advertising, v. 26, n. 1, 1997, p. 43-60.

JONES, F.G.. The Black Audience and the BET Channel. Journal of Broadcasting and Electronic Media, v. 34, n. 4, 1980, p. 477-486.

KATES. Steven M. (1999). Making the Ad Perfectly Queer: Marketing 'Normality' to the Gay Men's Community? Journal of Advertising, v. 28, n. 1, 1999, p. 25-37.

KATES, S. M. and SHAW-GARLOCK, G. The Ever Entangling Web: A Study of Ideologies and Discourses in Advertising to Women. Journal of Advertising, v. 26, n. 3, 1999, p. 214241.

MCCRACKEN, G. Culture and Consumption: A Theoretical Account of the Structure and Movement of the Cultural Meaning of Consumer Goods. Journal of Consumer Research, v. 13 , n. 1, 1986, p. 71-84.

McCracken, Grant. The Long Interview, Newbury Park, CA: Sage, 1988.

MICK, D. G. and BUHL, C. A Meaning-Based Model of Advertising Experiences. Journal of Consumer Research. v. 19, n. 3, 1992, p. 317-338.

PARHAM, T.A. and WILLIAMS, P.T. The Relationship of Demographics and Background Factors to Racial Identity Attitudes. Journal of Black Psychology, v.19, n. 1, 1993, p. 7-24.

PARKER, B. J. Exploring Life Themes and Myths in Alcohol Advertisements Through A Meaning-Based Model of Advertising Experiences. Journal of Advertising, v. 28, n. 2, 1998, p. 33-49.

RITSON, M. and RICHARD E. The Social Uses of Advertising: An Ethnographic Study of Adolescent Advertising Audiences. Journal of Consumer Research, v. 26, n. 3, 1999, p. 26277.

ROTHSTEIN, R. (1998). Bilingual Education: A Controversy Retrieved from http://www.pdkintl.org/kappan/krot9805.htm on Nov 26, 2002.

SPRADLEY, J. P. The Ethnographic Interview, New York: Holt, Rinehart, and Winston, 1979.

STARK, P. Blacks Attuned to Radio. Hollywood Reporter, Jan 4, 1993, p. 27.

STERN, B. B. Gender and Multicultural Issues in Advertising: Stages on the Researech Highway. Journal of Advertising, v. 28, n. 1, 1999, p.1-9.

STROMAN, C. A. Television viewing and self-concept among Black children. Journal of Broadcasting and Electronic Media, v. 30, n. 1, 1986, p. 87-93.

RAI - Revista de Administração e Inovação, São Paulo, v. 1, n. 2, p. 67-83, 2004. 

1984, p. 1-8.

Mass Media Effects and Black Americans. Urban Research Review, v. 9, n. 4,

SUAREZ-OROZCO, C. and SUAREZ-OROZCO. M. Children of Immigrants. Cambridge, MA: Harvard University Press, 2001.

THOMPSON, C. J. Interpreting Consumers: A Hermeneutical Framework for Driving Marketing Insights from the Texts of Consumers' Consumption Stories. Journal of Marketing Research, v. 34 (November), 1997, p. 438-455.

THOMPSON, C. J. and HAYTKO, D. L. Speaking of fashion: Consumers' uses of fashion discourses and the appropriation of countervailing cultural meanings, Journal of Consumer Research, v. 24, n. 1, 1997, p. 15-42.

THOMPSON, C. J. and HIRSCHMAN, E. C. Understanding the socialized body: A poststructuralist analysis of consumers' self-conceptions, body images, and self-care practices, Journal of Consumer Research, v. 22, n. 2, 1995, p. 139-154.

WEBSTER, F. The Changing Role of Marketing in the Corporation. Journal of Marketing, v. 56, n. 1, 1992, p. 1-17.

WRIGHT, P. Mass Communication: A Sociological Perspective. New York, Random House, 1986.

Data do recebimento do artigo: 08/03/2004

Data do aceite de publicação: 21/05/2004

RAI - Revista de Administração e Inovação, São Paulo, v. 1, n. 2, p. 67-83, 2004. 